\title{
Peace without Perfection: The intersections of Realist and Pacifist thought
}

\section{Introduction}

It is generally argued that realist political thought is the polar opposite of pacifism on questions of war and peace, with pacifism imposing a strict moral rejection of all war and realism freeing war of moral limitation entirely. Between these poles lies the via media of just war theory, which aims at the limitation of war through the development of moral and legal principles that can help us to determine when and how the waging of war may be considered just (Reichberg, 2008: 12-16). In constructing his 'moral continuum' from 'warism to pacifism', Duane Cady, for example, places 'war realism', the view that 'war itself is not an appropriate object of moral consideration', at the 'most extreme' end of his spectrum. Realist views on war, therefore, are seen as being more distant from and irreconcilable with pacifist thinking than the via media of 'just-warism' (Cady, 1989: 21-23). Just war theory, in this sense, appears in the attempt to reconcile the pacifist desire for peace with the reality of the ongoing threat of war. Such a positioning identifies pacifists, on the one hand, as being excessively moral, to the extent that they are out of touch with reality. Hence, in debates over the justifiability of violence in response to physical threats to ourselves or to others, pacifists will generally be confronted with 'realistic' analogies of personal self-defence against an assailant or to what are seen as the most obvious and compelling examples of 'just wars' from human history. Thus, as Cady puts it, '[e]ntertaining pacifist thoughts means being prepared repeatedly to face questions about reacting to a mugger and confronting Hitler as well as being realistic, self-righteous, and self-sacrificial' (Cady, 1989: 95; See also Holmes, 1989: 275-279). Those who fall at the other end of the conventional spectrum of thinking about morality on war, on the other hand, run the risk of being identified with the 'cynical realism' of the Machiavellian focus on 'naked "reason of state" at the expense of universal moral principle (Yoder, 1996: 34).

In an attempt to destabilise and reconfigure this conventional spectrum of views on the morality of war, this paper will propose that the realist view 'that it is wrong or impossible to think morally about war' potentially has much in common with a pacifist position, 'which accepts no war as 
morally permissible' (Yoder, 1996: 1). The broader purpose of making such an argument is to advance the development of what Dustin Howes (2009) refers to as a 'credible pacifism' and what I will here call a 'pacifist ethos'. ${ }^{1}$ For if it is the moral universalism or absolutism of pacifism that renders it un-credible from a political point of view, then perhaps we can draw upon the more politically-focused ethics of realism in developing new ways of thinking about and promoting a consistently anti-war position without drifting toward the conventional via media of just war theory. If such an argument can be established with any credibility, it might then serve to dislodge just war theory from its comfortable middle ground between realism and pacifism, in turn making it more difficult to advance moral rationales for war that may at times serve to enable rather than limit the possibilities for states to justify their wars.

The orientation for this article, in this context, is to consider the possibility of developing a pacifist ethos that maintains an absolute rejection of the morality or legitimacy of war as a tool of statecraft by engaging in what Brett Steele (Steele, 2007) has termed a 'reflexive realist' approach to the problem. 'Reflexive realism', which is associated with the work of Michael Williams (Williams, 2007; Williams, 2005), Ned Lebow (Lebow, 2003), William Scheuerman (Scheuerman, 2007; Scheuerman, 2011), and Vibeke Schou Tjalve (Tjalve, 2008; Tjalve and Williams, 2015), amongst others (Molloy, 2006; Molloy, 2010; Cozette, 2008b; Cozette, 2008a), is particularly valuable in this context, as it emerges out of sustained reflection on the interplay of ethics and politics that aims 'to restore classical realist principles of agency, prudence and the recognition of limitations as part of an attempt to provide a practical-ethical view of international politics' (Steele, 2007: 273). Classical Realist ethics, as Felix Rösch (2016: 82) argues, can in this context be deployed 'for a revival of a democratic citizenship in global public spheres through the promotion of scepticism, (self)criticality and intellectual humility.' Seán Molloy's 'rhizomatic reading of Realism' is also relevant here, as it gestures toward a body of realist theory in IR which 'despite the epic history with which it is often afflicted, does not remain stable over time; rather, it mutates, shifts in nature, stabilises and destabilises. In short it acts pretty much as one would expect a rhizome to act' (Molloy, 2010: 388). In adopting this approach, my suggestion here is not, therefore, that the 'true' versions of pacifism and realism are closer than we have previously suspected; rather, the intention is to engage in a creative 
theoretical act designed to provoke or inspire new ways of thinking about pacifism that don't fall into worn-out clichés and expectations of a fundamental idealist/realist divide on questions on war and peace. So while it may be tempting to simply dismiss pacifism based on the realist belief in the inevitability of violent struggle, or to dismiss realism on the grounds that it is morally nihilistic, I will aim to show that such lines can in fact be fruitfully crossed. Such a project proceeds from the belief that there are tenable and useful ways in which we can bring realist ethics to bear on the apparently intractable problem of inter-state or inter-communal warfare that may be less susceptible to the kinds of knee-jerk dismissal that pacifists routinely experience. We might, therefore, agree with Michael Walzer's (Walzer, 1992: 4) claim in Just and Unjust Wars that 'Realism is the issue', but disagree on the nature of that issue itself and where it may take us.

The possibility of experimenting with a reflexive realist approach to pacifism also presents itself in part as a consequence of the rhizomatic character of the pacifist tradition. Countless works have been published that detail an array of different pacifisms that have emerged over the millennia from both religious and secular theorising (See, for example, Brock, 1998; Brock, 1970). John Yoder (1976) identifies eighteen schools of pacifism in his classic overview of religious variants of pacifism, Nevertheless. Each version of pacifism may be motivated by a variety of different impulses: 'that love endures and can overcome; that hatred destroys; that the duty of a human being is to diminish hatred and promote love; that man is one; that this implies unity with the enemy; that the spirit does inform human life and can prevail over the brutal in man' (Cromartie et al., 1990: x). Key distinctions that need to be thought out by anyone engaging with pacifism relate to the violence that is being opposed: is it only warfare, or is violence against individuals at the domestic or local level also morally wrong? Is civil war as (or more) morally reprehensible than interstate war? Moreover, as Robert Pickus has noted, '[d]iffering strands in the pacifist tradition emphasize the personal refusal to participate in war, opposition to all preparation for war, or the development of alternatives to war in the resolution of political conflict' (Cromartie et al., 1990: ix). Moral philosophy, for its part, tends toward a categorisation of pacifisms into deontological and consequentialist types, with the former more concerned with the moral repugnance of killing in general and the latter with the failure of war to 
achieve its purported ends (Kinsella and Carr, 2007: 33-36). Pacifism can, in short, be motivated by a wide array of moral, social or political concerns and can be manifested in a variety of actions.

The meaning of pacifism becomes even murkier when considering the enormous literature on what is sometimes referred to a 'qualified' or 'contingent' pacifism, where the desire to see the end of war is tempered by an acknowledgement that sometimes war can, at least theoretically, be considered to be the moral or just thing to do. It is in this area that lengthy debates have taken place, with some arguing that reconciliation between pacifism and just war theory can be brought about (Sterba, 1992; Sterba, 1994; Sterba, 1999; May, 2012; May, 2015) and others responding that such a reconciliation is theoretically nonsensical (Reitan, 1994; Reitan and Sterba, 1994; Holmes, 1999; Neu, 2011). In this dispute, I side with the argument advanced by Michael Neu, who refuses to accept that pacifism can accommodate any moral argument for war, insofar as:

just war theorists will always insist that war can be a justified means to protect the rights of innocents against large-scale criminal assaults; and pacifists, on the other hand, will always insist that such a justification misses out on a fundamental moral truth, namely, that allegedly justified wars necessarily involve acts that cannot be justified (Neu, 2011: 428).

Whilst acknowledging the depth and complexity of contingent pacifist thought, as well as the increasingly detailed and nuanced field of just war theory (Lazar, 2017; Lazar, 2010; Shue, 2013; McMahan, 2010; Pattison, 2016), the argument being advanced here is that a significant line is crossed when one moves toward developing jus ad bellum and jus in bello rules. So while there is no doubt about the desire of just war theorists to impose positive moral limits on the justification and conduct of war, I aim to show that all such attempts to define the conditions under which war may be considered morally valid stand in problematic relation to both realism and pacifism, throwing into doubt the conventional spectrum of views on the subject.

In attempting to shift some of these sedimented ideas about the spectrum of moral thinking on war and peace, I adopt a limited definition of a pacifist ethos as a consistent, politically-engaged opposition to war that simultaneously recognises the impossibility of the permanent eradication of 
war. This version of pacifism may be construed as resting upon an underlying deontological rejection of war, but draws upon realist ethics in considering how best to operationalise that moral inclination in a context in which there can be no expectation that it can ever be fully realised. The pacifist ethos, informed by classical realist thought, might in this sense be understood as 'a sub-optimal yet beneficial normative vision - an exercise of creative potential meant to responsibly limit excess but not all alternatives' (Hom and Steele, 2010: 285). I developing the idea of a pacifist ethos, I intend to provide a richer theoretical grounding for some of the existing work on pacifism that gestures toward the need for greater credibility (Howes, 2009) or political engagement (Mantena, 2012; Ott, 2012; Alexandra, 2003).

The argument in favour of a pacifist ethos is developed in two parts. In the first section, I examine the classical realist theorisation of the links between human nature, power and war and explain how this terminates in a critique of pacifism from a realist perspective. In the second part of the paper I pivot toward the points of commonality between classical realist and pacifist positions. Perhaps unsurprisingly, this focuses primarily on the shared concern with the moralization and justification of war most prevalent in just war theory, which is critiqued and/or rejected in both realist and pacifist thought. I then go on to argue that this shared critique of just war theory can and has acted as the basis for non-violent and pacifist political strategies and that this could represent an underexploited political resource for those concerned with reducing the amount of violence in the world.

\section{The Disjunction of Pacifism and Classical Realism: Human Nature and War}

Any attempt to work through the implications of classical realist thought and its relation to pacifism necessitates a confrontation with one's own beliefs about human nature and an understanding of what flows from that belief. The question that necessarily follows is whether an acceptance of the conflictprone nature of humankind rules out in advance the embrace of a consistent pacifist position. For, as Kenneth Waltz puts it in Man, the State and War, the starting point for the classical realist position is one in which 'the locus of the important causes of war is found in the nature and behaviour of man' (Waltz, 1970: 16). For classical realism, this means an acceptance of the inherent selfishness, egotism, and violence inherent in human beings. The consequences of such a rendering of human life are that 
human society is imperfect, imperfectible, and contingent. More importantly in this context, it points to the impossibility of ruling out war as an expression of extreme political conflict, in turn suggesting the need to be prepared for war in order to guarantee survival.

For the realist thinkers that form the basis of the argument to follow, Carl Schmitt, Hans Morgenthau, and Reinhold Niebuhr, the acceptance of the ineradicable possibility of war and the need to be prepared for such wars lies at the heart of their political thought. In following Hobbes' (2002) pessimistic view of the state of nature, Schmitt declares in The Concept of the Political (Schmitt, 1996: 58, 61) that 'the problematic or unproblematic conception of man is decisive for the presupposition of every further political consideration' and that 'all genuine political theories presuppose man to be evil, i.e., by no means an unproblematic but a dangerous and dynamic being.' Morgenthau, despite being much more wary of the pernicious influence of Hobbes (Morgenthau, 1959), likewise centralises the power-hungry human nature in his theory of international politics, with the first of his six principles of political realism declaring that 'politics... is governed by objective laws that have their roots in human nature' (Morgenthau, 2006: 4). The substance of that human nature had been more clearly elaborated in Scientific Man vs Power Politics, in which Morgenthau (1974: 9) posited the existence of a 'lust for power that is common to all men', derived from both an 'elementary egoism' (Tellis, 2006: 608) geared toward survival and a more expansive 'desire to maintain the range of one's own person with regard to others, to increase it, or to demonstrate it' (Morgenthau, 1974: 193). Power, in other words, can be seen as both a means to an end and as an end in itself, with both expressions having problematic outcomes. This assessment of human nature lies at the foundation of Morgenthau's dismissal of the naïve 'scientific man' who seeks to solve the problems of the world though the rational design of institutions and norms geared toward cooperation and peace. The problem, for Morgenthau, is that '[n]o such community of rational interests and values exists... on the international scene, at least not permanently and universally' (Morgenthau, 1974: 107).

How, then, does this basic image of human nature correspond to an international political theory? $?^{2}$ For Morgenthau, the political must be understood as an intensity of differentiation or antagonism that can become manifest in a wide array of social relations, with the connection between 
them being that 'they all have the will to power as the psychological factor at their base' (Morgenthau, 2012: 106). Thus, in accordance with the discussion above, the political is the sphere in which the basic human urge 'to maintain... to increase... or to manifest' power is expressed in its most intense form. Schmitt makes a similar claim, maintaining that ' $[t]$ he fundamental theological dogma of the evilness of the world and man leads, just as does the distinction of friend and enemy, to a categorization of men and makes impossible the undifferentiated optimism of a universal conception of man.' Hobbes' thought, according to Schmitt, is exemplary is this regard as 'a pessimistic conception of man is the elementary presupposition of a specific system of political thought' in which 'the conviction of each side that it possesses the truth, the good, and the just bring about the worst enmities, finally the war of all against all' (Schmitt, 1996: 65).

This 'problematic conception of man' is, therefore, thoroughly implicated in both Schmitt and Morgenthau's construction of their theories of politics and sovereignty. For Schmitt, the state is an entity in which internal cohesion comes about through opposition to external foes. This friend/enemy distinction, which 'denotes the utmost degree of intensity of a union or separation, of an association or dissociation' is, for Schmitt, the essence of the political. In its most extreme forms, political conflict generates 'the real possibility of physical killing'. Hence, he proclaims that '[w]ar follows from enmity. War is the existential negation of the enemy. It is the most extreme consequence of enmity'. Importantly, however, these strong claims connecting the inherent evil of man with the friend/enemy distinction of politics and the unending possibility of war are tempered by the recognition that the extreme situation 'does not have to be common, normal, something ideal, or desirable' (Schmitt, 1996: 33). Rather, it is something that exists and will continue to exist, even if only as a possibility, as an inescapable element of the political nature of human life (or the political life of human nature). A politically viable pacifism, in this context, seems out of reach.

Reinhold Niebuhr's brand of protestant realism, in introducing a deeper theological angle to these debates, adds another dimension to the realist critique of pacifist theory and practice. As it is for Schmitt and Morgenthau, the inherent selfishness of man is Niebuhr's 'basic cause' for social problems, including war. This understanding of the basic egoism of man and the political consequences that flow from it form the basis of his major contributions to political theory. In Moral 
Man and Immoral Society, for example, Niebuhr argues that '[e]very group, as every individual, has expansive desires which are rooted in the instinct of survival and soon extend beyond it. The will-tolive becomes the will-to-power' (Niebuhr, 2013: 18). Likewise, in The Children of Light and the Children of Darkness, it is posited that 'egoistic corruption of universal ideals is a much more persistent fact in human conduct than any moralistic creed is inclined to admit' (Niebuhr, 2011: 22). Like Morgenthau and Schmitt, therefore, Niebuhr cautions against the embrace of rationalistic programs for social improvement, on the grounds that humans are simply not capable of achieving the demands of such programs. In short, this generates, according to Waltz (1970: 33), a Niebuhrian maxim of 'do not expect too much'.

Waltz rightly argues, following on from this, that Niebuhr is more interested in the 'secondary causes' of social ills, such as institutional forms, which lead to conclusions about 'just what to expect under different conditions, which conditions must be changed to minimize unwanted effects and achieve others, and, generally, what the rules of conduct must be for the conscientious citizen or politician' (Waltz, 1970: 33). Niebuhr was, in this vein, particularly interested in stressing the value of democratic institutions over more authoritarian or tyrannical alternatives. Such commitments, as imperfect as they may be in reality, may then require the resort to force at times when tyranny threatens democratic societies. In a world of sin and egoism, Niebuhr argues, '[g]overnments must coerce' and 'there is always an element of evil in this coercion' (Niebuhr, 1940: 107-109). Niebuhr's approach, therefore, like that of the other realist theorists discussed above, shares a concern with a political life that is invariably riddled with tragedy, imperfection, hypocrisy and marked by the necessity of taking decisions based upon a calculus of the 'lesser evil'.

This approach to politics flows through to Niebuhr's stinging critique of the perfectionism of Christian pacifism, which he sees as being grounded in 'utopian illusions' (Niebuhr, 1940: 103). While accepting that the absolutist orientation toward an ethic of love has an important place in Christian society, he nonetheless argues that pacifist ideologues who pay no heed to the 'facts of human existence' engage in heresy (Niebuhr, 1940: 104-105). This heresy resides in the rejection of the Christian doctrine of original sin and the related belief that Jesus' ethic of love could be made real, rather than simply representing a horizon of perfection which man can only hope to approximate in 
the tragic and sinful reality of life. A properly Christian approach to the imperfection of political life, according to Niebuhr, would pay proper heed to the guilt that accrues to all human activity, remembering 'the ambiguity of even his best actions' (Niebuhr, 1940: 118). In the push for the realisation of an absolute and eternal peace, based upon the realisation of Jesus' ethic of love, the pacifist runs the risk of failing to recognise how such perfectionist principles are themselves 'corrupted by self-righteousness' (Niebuhr, 1940: 119). It is for this reason that the pacifist denunciation of those who show a preparedness to use violence to counter tyrannical political alternatives amounts to a heresy.

The immediate issue that presents itself here lies in the realist expectation that any genuinely political activity must countenance the possibility of using violence and fighting wars against its enemies. It is very difficult to see how a 'pacifist politics' could be anything other than paradoxical in this context. Schmitt recognised such a paradox, arguing that:

[i]f pacifist hostility toward war were so strong as to drive pacifists into war against non-pacifists, in a war against war, that would prove that pacifism truly possesses political energy because it is sufficiently strong to group men according to friend and enemy. If, in fact the will to abolish war is so strong that it no longer shuns war, then it has become a political motive, i.e., it affirms, even if only an extreme possibility, war and even the reason for war' (Schmitt, 1996: 36).

Schmitt, in this sense, rebuffs the very possibility of a politically-engaged absolute pacifism, insofar as all political activity is necessarily engaged in the making of friend/enemy distinctions and recognising the 'real possibility' of war against the enemy. It also emphasises the dramatic change that takes place in the slippage from a consistent pacifism toward just war theory: Only the latter can constitute a political motive insofar as it allows for the possibility of fighting on behalf of a particular cause. This is obviously troubling for any attempt, such as this one, to experiment with a reconciliation of realist and pacifist principles.

The question then becomes: where can we go from here? Is it simply a choice between a naïve and self-defeating belief in the rational perfectibility of man as opposed to a pessimistic view of 
human nature as egotistical and prone to conflict? Must anyone of a pacifist inclination necessarily adopt the former view over the latter? As Waltz (1970: 30-31) puts it, the pessimistic view of human nature 'can explain the necessary imperfections of all social and political forms' and can be 'useful in descrying the limits of possible political accomplishment', but can we go anywhere else with such a view? Does a commitment to a realist perspective on international politics necessitate an acceptance of war-fighting as a necessary or lesser evil or as an unavoidable dimension of the tragic nature of international politics? Is it right, in this sense, to view realism as being at the extremely permissive end of the scale on thinking about the legitimacy of war as a tool of statecraft? Is it necessary to reject pacifism for its failure to recognise reality and instead embrace some limited form of just war theory? In the section to follow I aim to demonstrate that these choices are not as black and white as they are often presented, and that realist thought actually offers some very useful resources for the development of new theories and strategies for pacifist politics.

\section{The affinities of Realism and Pacifism: The critique of the moralisation of war}

Where, if at all, can we identify the intersections of realism and pacifism? In this section, I will argue that there are two dimensions of realist thought through which affinities with pacifism and nonviolence could be established. The first concerns the refusal to countenance the moralization of war in realist thought, which provides a theoretical commonality with pacifism, and the second concerns the ways in which a realist political philosophy might be useful in enacting non-violent political strategies in international politics. Whilst these theoretical and practical dimensions are fundamentally entwined, I will address each of them in turn.

One of the most under-appreciated and under-exploited dimensions of realist theory lies in its refusal to countenance the moral justification of war. For some theorists identified with the classical realist tradition, this refusal emerges from the relativist position on morality that is tied to the realist conception of politics and sovereignty: Where there is no capacity to exercise universal judgement there can be no universal moral rules. Thus, for Hobbes (2002: 57), for example, the 'warre of every man against every man' is one in which 'nothing can be Unjust' insofar as '[t]he notions of Right and Wrong, Justice and Injustice have there no place'. Such a conclusion is, for Hobbes, a necessary 
corollary of the absence of a sovereign power, as "where there is no common Power, there is no Law: where no Law, no Injustice'.

While Hobbes was in this passage thinking in terms of the formation and disintegration of states, we see a similar line of reasoning in Carl Schmitt's thinking on civil and international conflicts. In Schmitt's thought, the concepts of crisis and decision as markers of the role of the sovereign in political life provide the theoretical background against which war is understood as necessarily extranormative. War, as an extreme crisis situation, must be understood as a symptom of the break-down of norms of justice and morality, whether on the intrastate or interstate level. In such a context, the expectation of normative or legal constraints on warfare is misplaced, as 'the norm is destroyed in the exception' (Schmitt, 1985: 12). 'That justice does not belong to the concept of war', Schmitt argues, 'has been generally recognized since Grotius'. All claims regarding the waging of just war, therefore, 'usually serve a political purpose' (Schmitt, 1996: 49).

This, in turn, leads to Schmitt's widely-cited polemic against the 'war for humanity', captured most pithily in his paraphrasing of Proudhon to the effect that "whoever invokes humanity wants to cheat'. The problem with invoking humanity in justifying war, from this perspective, lies not only in the logical problem of claiming to fight against a group that must necessarily be a part of humanity, but also in the fact that the deployment of 'humanity' for this purpose creates a situation in which 'war can be driven to the most extreme inhumanity' (Schmitt, 1996: 54). Schmitt puts this case for the amorality of war starkly in The Concept of the Political, arguing in what might otherwise appear to be pacifist terms that 'no program, no ideal, no norm, no expediency confers a right to dispose of the physical life of other human beings... It is a manifest fraud to condemn war as homicide and then demand of men that they wage war, kill and be killed, so that there will never again be war' (Schmitt, 1996: 48). This, of course, does not make Schmitt a pacifist, as he clearly allows for the justification of war for the purposes of national survival in an extreme conflict with an enemy (Schmitt, 1996: 49), as discussed above. Yet what is interesting about Schmitt's position - and, I would argue, the realist position on war in general - is precisely that it dismisses the moral justifications for war that are found in the liberal-internationalist or Christian just war tradition. In fact, it can be recognised that the very concept of a 'war for peace' or a war for humanitarian purposes, is seen as a major move toward 
removing the limits imposed by a more formalistic understanding (or 'bracketing') of the place and conduct of war under the jus publicum Europeum (Schmitt, 2003; Schmitt, 2007).

Despite the rejection of moral war that we find in classical realist theory, it still seems a large leap to draw a connection with the moral rejection of war espoused by pacifists. This is particularly problematic if we accept the Hobbesian/Schmittian claim that morality and justice only accrue in the context of the sovereign state (Walzer, 1992: 10-11). As Gabriella Slomp argues, the adoption of this approach to just war theory 'is controversial for anyone who wants to avoid the plunge into the abyss of extreme relativism, because they must reject the view that any war is just for those who fight for it' (Slomp, 2006: 440). Such moral relativism, according to Slomp, necessarily maintains a 'gap between Schmitt and pacifism' that cannot be bridged (2006: 436).

With this criticism in mind, we can then perhaps turn to the variation on moral thought espoused by Han Morgenthau, who allows for the existence of ostensibly universal moral values and principles of justice, but argues (in a response to Martin Wight's misinterpretation of a section on Hobbes in Morgenthau's In Defense of the National Interest (1951: 34)) that such principles 'receive their concrete meaning from the political situation within which they are called upon to operate' (Morgenthau, 1959: 502). Such a perspective allows for a reconciliation of abstract moral principles with political realities, as while there is no expectation that such principles can ever be fully realised in practice, this does not negate the principles, nor demean their value to practical politics. Adherence to principles of pacifism or non-violence, from this point of view, does not then lead to the expectation that such principles can be fully realised in practice; rather, prudent application of such principles becomes necessary in response to contingent yet concrete political situations.

Despite this departure from 'Hobbes's extreme dictum that the state creates morality and law and that there is neither law nor morality outside the state' (Morgenthau, 1951: 34), Morgenthau's understanding of the role of morality in relation to political reality leads him back toward a critique of the moralisation of war similar to that espoused by Schmitt. In this vein, he writes in Politics Among Nations of the dangers of 'nationalistic universalism' and its links to the historical emergence of total war. In keeping with Schmitt's critique of the war for humanity, Morgenthau (2006: 280) makes the claim that: 
When a nation invokes 'world public opinion' or 'the conscience of mankind' in order to assure itself, as well as other nations, that its foreign policies conform to the standards shared by men everywhere, it appeals to nothing real. It only yields to the general tendency... to raise a particular national conception of morality to the dignity of universal laws binding upon all mankind. The confidence with which all the antagonists in the international arena believe themselves to be supported by world public opinion with respect to one and the same issue serves only to underline the irrationality of the appeal.

Yet despite the purported irrationality of such claims, they remain vital to the mobilisation of the masses in contemporary warfighting. In order to fulfil the demands of a nationalistic universalism, Morgenthau claims, 'a moral issue was needed for whose defense or attainment war was to be waged. In other words, war had to be just on one's own side and unjust on the side of the enemy in order to evoke moral enthusiasm in support of one's own cause and hostile passion against the enemy' (Morgenthau, 2006: 380). Once again, what we can see here is that the realist attacks on moral arguments in support of war lead to the conclusion that a) war is always and everywhere a state of exception to which no moral constraints can effectively be applied and b) that attempts to institute such moralization can lead to a multiplication and intensification of war in general.

It is precisely at this point, I would argue, that we might identify a defensible and useful convergence of realist and pacifist thought. In Robert Holmes' recent piece on 'The Metaethics of Pacifism and Just War Theory', the conclusion is reached that from a pragmatic pacifist perspective '[n]o actual, probable, or possible whole wars in the modern world are morally permissible' (Holmes, 2015: 13, emphasis added). Hence:

what both sides do in a war is wrong, and the whole war, which is the joint product of what they do, is wrong. Pacifism and [just war theory], in addition to asking different moral questions, operate with different assumptions about the ontology of war and the relevant historical frame of reference regarding the scope of war. This makes it highly improbable that they will converge (Holmes, 2015: 13). 
This position, in emphasising the unbridgeable gap between just war theory and pacifism, leaves a space in which realist thinking should fall. In limiting or 'bracketing' (Schmitt, 2003; Schmitt, 2007) the possible justifications for war, the point of the realist critique is intended to reduce the likelihood of imperialist wars claimed to rest on moral or ideological grounds, as well as the intensity and brutality of such total wars. In this sense, pacifism and realism have much in common in the analysis of the actual or potential moral quality of warfighting and this sets them decisively apart from the moral justifications for war found in just war theory. We can at least reach a tentative conclusion, then, that realism might be situated more closely to pacifism on the spectrum of attitudes toward war than Christian or liberal just war theory. This accords to some degree with Howes' view that 'a proper rendering of the philosophical landscape on the question of violence and war would depict the split between just war theory and pacifism as the defining feature of thought on the subject in the Western tradition' (Howes, 2015: 379) .

Yet even this conclusion, as Howes' recent work has argued (Howes, 2015), may be subject to serious challenge. For if we accept the permanent possibility of political crisis that may descend into open warfare, does that not also require us to accept that such wars are in some circumstances just, legitimate or at least necessary? In other words, is the gap between views of war as morally right in some circumstances and war as a 'necessary evil' really significant? Howes, who has made some very powerful arguments around the need to develop a 'pragmatic pacifism' (Howes, 2009), argues that there are 'strong mutually reinforcing tendencies' between realist thinking on the necessity of violence and just war thinking, insofar as 'both rationalise the waging of war on ethical grounds' (Howes, 2015: 384). This argument, therefore, turns on how much of a distinction we find between the moralisation of war in just war theory and the rationalisation of war as a 'necessary evil' in realist thought. I want to argue here that the gap between these perspectives is greater than Howes suggests and that the realist view opens doors to non-violence and pacifism that are not available to the just war theorist.

While it may indeed be the case that arguments around survival and the necessity of war in an unpredictable international political realm have some moral content, it could also be argued, in 
keeping with Schmitt, that 'moral views on war do not provide moral justifications for war' (Slomp, 2006: 445, emphasis added). The point here is that refusal to accept that any war can be 'just' or 'moral' leaves the possibility of consistent pacifist activism open, while embrace of just war theory immediately closes off that possibility and goes further in potentially allowing a proliferation of justifications for war none of which can be effectively judged by any authority other than the victorious party. While this does not overcome the 'fundamentally tragic' nature of war in the extreme situation, it aims 'to rid us of the ease with which we regard the taking of human life' (Ryan, 1983: 520) and to 'do justice to the nuances and complexities of the violent moral world we occupy' (Neu, 2011: 432).

The question that remains, of course, is 'is that enough?', for a consistent pacifism would appear to need to reject not only the moralization of war, but also the justification of wars of selfdefence, a position that no realist thinker - focused as they are on survival as a foundational principle - would be prepared to accept. This is an immensely challenging issue for any pacifist thinker, but is intensified for any realist-inclined pacifist in the sense that a seemingly unrealistic, extreme moralism leading to self-sacrifice in the face of an existential threat is required in order to reject the justification of war based on self-defence (Ryan, 2013; Ryan, 2015; Rodin, 2002). Pacifism, from this point of view, represents a moralisation of politics even more extreme than that proposed by just war theorists, precisely the problem identified by Niebuhr. Can it really be the case that the only acceptable alternatives in the face of existential dangers are non-violent ones? Does the case for pacifism run headlong toward self-destruction in the refusal to distinguish between those fighting for good or evil?

Two related possibilities for a realist-informed pacifist ethos present themselves at this point: a case must be made for the necessity of taking the world 'as it is' in attempting to forge non-violent responses to existential threats and, in association with this, it could be argued that defensive war is politically imprudent and unlikely or unable to achieve the objective of survival (and that non-violent strategies are more likely to achieve the desired outcome) (Chenoweth et al., 2011). Both of these possibilities gesture toward the exploitation of realist thought as a guide to strategic, non-violent political action. As Waltz (1970: 19) made clear in Man, the State and War, '[p]essimism about the chances of ultimate success, in eliminating war for example, is not identical with a statement that 
nothing can be done about our present plight'. In this vein, Reinhold Niebuhr provides some guidance on how a realist activism might proceed, proposing that:

The children of light must be armed with the wisdom of the children of darkness but remain free from their malice. They must know the power of self-interest in human society without giving it moral justification... They must have this wisdom in order that they may beguile, deflect, harness and restrain self-interest, individual and collective, for the sake of the community (Niebuhr, 2011: 41, emphasis added).

On this front, some interesting recent research has highlighted the 'realistic' or 'pragmatic' credentials of pacifists such as Gandhi and Martin Luther King Jr., running contrary to the popular image of such figures as absolute pacifists or naïve idealists. An important recent example of this kind of research is Karuna Mantena's study of Gandhian nonviolence. Drawing upon the critiques of normative political philosophy put forward by Raymond Geuss (2008; Geuss, 2010) and Howard Williams, Mantena makes a strong case for 'another realism, one that neither forsakes an agenda of reform nor sacrifices ethics at the altar of power politics' (Mantena, 2012: 456). Gandhi, from Mantena's perspective, is an exemplar of such a politics, insofar as 'Gandhi's understanding of politics was fundamentally realist, and it is this underlying realism that renders nonviolence a plausible practical orientation in politics and not purely a moral proposition, ethical stance, or standard of judgment' (Mantena, 2012: 457). At the core of this realism, Mantena (2012: 457) argues,

was a contextual, consequentialist, and moral-psychological analysis of a political world understood to be marked by inherent tendencies toward conflict, domination, and violence. Animated by a powerful negative horizon of violence, Gandhi was attuned to the unintended consequences of political action, especially the ways in which idealism and moralism, despite the best of intentions, could enable ideological escalation and violence. 
What we can see, therefore, is a concern shared by a pacifist like Gandhi and the realists discussed above that 'idealism can facilitate tendencies toward ideological entrenchment in politics' (Mantena, 2012: 457) that may in turn make the resort to violence more likely and more attractive to the protagonists in a political conflict.

From Gandhi's perspective, Mantena suggests, the realities of life that must be negotiated in any political conflict are 'the necessary starting points for the work of politics' (Mantena, 2012: 468). In keeping with much realist and poststructuralist theorizing, this requires recognition that politics is an antagonistic sphere, with variations in 'relations of power, legacies of domination, forms of disagreement, and stages of polarization' all having an impact on the context in which interaction takes place. Beginning from a place of uncertainty and contingency, Gandhi's non-violent action (or satyagraha), must always be 'dynamic, strategic, and contextual' rather than being driven by absolute ideological convictions. Mantena is keen to emphasise, however, that this does not require an abandonment of the moral altogether, rather that it requires a form of political action in which the agent must "navigate the terrain between morally strict categorical imperatives and morally lax decisionism' (Mantena, 2012: 464). Such a move requires a shift away from consequentialist thinking, as this allows political actors to justify themselves in terms of good outcomes being achieved through violent means. The negative outcomes of such an approach, which focuses too heavily on the ends over the means, can be ameliorated through a more realistic approach, insofar as 'from the standpoint of political action, the is/ought question is reconfigured as a means/ends question, one in which the tighter imbrication of the normative and the empirical that realism recommends can be enabling rather than constrictive' (Mantena, 2012: 468).

A similar argument has been advanced by Dustin Howes, who agrees with Mantena's interpretation of a Gandhian ethics of non-violence as a viable and pragmatic possibility for political engagement. For Gandhi, Howes argues, '[n]onviolence demands moving away from abstract goals and utopianism, which often tend toward violence' (Howes, 2013: 437). From this basis, he advances the concept of 'credible pacifism', in which non-violence appears as a rational, achievable, and historically successful alternative to the waging of war in international and domestic politics. Hence: 
Pragmatic pacifism claims that the task of developing new political strategies to confront violence is never complete and that violence will always reappear. However, it retains an ideological element in forwarding two principles: 1) as yet unseen circumstances can be addressed by creative nonviolence, and 2) politics and power have certain characteristics that make violence unnecessary (Howes, 2013: 437).

In affirming his core claim that violence 'is no more or less effective than any other political method', Howes seeks to elevate the prudential arguments for non-violent politics. Good intentions, from this perspective, are not a sufficient rationale to allow for the moral justification of violent politics, as:

Actions motivated by good intentions that in practice lead to bad outcomes are just as often the hallmark of those who embrace the use of violence as those who reject it. The good intentions of keeping us safe, overthrowing a corrupt regime, punishing criminals or defending freedom frequently end up being a catalogue of excuses for violence that leads to more conflict and suffering and stands little chance of political success. The weight of extensive empirical evidence demonstrates that the practitioners of violence are more often the tragic idealists than are pacifists (Howes, 2013: 438).

Such conclusions rely heavily on Chenoweth and Stephan's empirical analysis of the success of nonviolent civil resistance movements, which 'concludes that nonviolent civil resistance works, both in terms of achieving campaigns' strategic objectives and in terms of promoting the long-term wellbeing of the societies in which the campaigns have been waged. Violent insurgency, on the other hand, has a dismal record on both counts' (Chenoweth et al., 2011: 222).

Whether intentionally or not, such studies affirmatively answer a rhetorical question posed by Schmitt in The Concept of the Political: 'And, after all, could not the politically reasonable course reside in avoiding war?' (Schmitt, 1996: 33). This sentiment also intersects with Niebuhr's analysis of Gandhi's non-violent politics, in which he argues that the line between non-violence and violence is not absolute, but that non-violence can and should be seen as a prudent course of action in many political conflicts (Niebuhr, 2013: 240-242). In doing so, Niebuhr acknowledges the challenge of Gandhi's efforts 'to harmonise the insights of a saint with the necessities of statecraft' and concludes 
that '[n]on-violent coercion and resistance, in short, is a type of coercion which offers the largest opportunities for a harmonious relationship with the moral and rational factors in social life' (Niebuhr, 2013: 243-251). While the connections between pacifism, non-violence, and classical realism are by no means clear-cut and straightforward, there is a degree of depth and continuity of realist claims in relation to pacifism that should not be ignored and that may produce some challenging new thinking on questions of war and peace.

\section{Conclusion: The Political Value of a Pacifist Ethos}

There are a number of potential arguments about pacifism and realism that flow from the preceding analysis. First, I want to maintain that the standard rendering of the spectrum of positions on war and peace is not as obvious and stable as it is usually claimed to be and, specifically, that just war theory needs to be recognised as being a potentially more permissive theory of war than the realist alternative. Flowing from this revision of the standard theoretical accounts of the ethics of war, it can be argued that, at its very minimum, a pacifist ethos informed by realist political thought can be deployed to deprive war and war-makers of the oxygen of 'justice'. It is worthwhile noting that such a position accords with that taken up by Immanuel Kant in Perpetual Peace, in which he castigates the 'sorry comforters', Grotius, Pufendorf and Vattel for their claims that 'right' has any meaning in 'the politics of war'; a critique grounded in the 'malevolence of human nature, which can be seen unconcealed in the free relations of nations' (Kant, 1999: 326). This is Kant in his most realistic guise, recognising the state of war as one external to questions of justice and morality, in which concepts of justice and right only serve to inflame the violence between states. While I clearly cannot claim to support a Kantian, rationalist solution to this problem, the identification of this inflammatory conception of war and justice is certainly a shared concern from a realist point of view. What it amounts to in practice is a concerted refusal to provide those with the capacity to make war with a ready set of moral principles and standards of justice that can be deployed selectively and cannot hold any consistent traction, precisely as a consequence of the extra-normative context in which they are used. The use of 'civilian protection' and humanitarian arguments by the Saudis in support of their 
brutal attack on Yemen (Alhaidar, 2015) is but one example of how the moralisation of war can be deployed at will by those seeking to advance their political objectives. Normative objections to the effect that such campaigns don't really meet the theoretical standards of just war theory offer little protection to those victimized in such cases.

Yet the question remains as to whether a consistent rejection of war as a moral act can be sustained without entering into deeper moral and political perversities. The rapid and brutal emergence of the Islamic State serves as a troubling example of the challenges of a consistent pacifism. How, in the face of a group with immediate genocidal intent, should other powers react? On the one hand it might be tempting to invoke just war theory in order to support the claim that it is sometimes both necessary and morally right to act in the face of evil. On the other, it must be recognised that any exercise of material power aimed at destroying the Islamic State must necessarily be greater than the force that the Islamic State is currently capable of resisting, as the extreme aerial bombardment and ground fighting in Raqqa and Mosul currently illustrates. I would suggest that the baseline for any pacifist response to this situation is to insist that there is no possibility of justice being served, either through the violence being enacted by the Islamic State or by any interventionist force aimed at stopping it. Such a conclusion is of no help to the policy-maker involved in the making of life and death decisions around warfare, but that is exactly the point: Anyone seriously committed to norms of non-violence or pacifism should offer no such guidance or comfort; the responsibility for the exercise of violent power must rest with those who make the decisions and not be externalised onto abstract principles of justice. As Neu (2011: 431) argues, 'justified warriors should feel perplexed, anxious, and remorseful about what they do... they should feel guilt, perhaps shame... they should not be cheerful and morally enthused about what they do.'

Yet while criticism of the moralisation of war for human rights or humanitarian purposes is relatively straightforward, it is around the realist principle of war as a political necessity that a pacifist ethos faces deeper challenges. It is here, I would suggest, that the more strategic dimensions of realist thought can come in to play, allowing the pacifist to formulate effective responses to 'wars of necessity' (e.g. for the survival of the state) without being limited to moral exhortations and condemnation of the combatants. As Mantena argues, 
Rather than the construction and legitimation of norms, as the starting point of politics and political theorizing, the realist call to attend closely to dynamics of power, conflict, and domination can be mobilized on behalf of principled and progressive politics. This... seeks to enable another realism that can navigate a way out of its traditional impasses, a transformational realism that need not begin and end in conservatism, moral equivocation, or pure instrumentalism (Mantena, 2012: 457).

Such a perspective is very much in keeping with the warnings of the dangers of universal programmes for justice and the associated 'universal nationalism' that was such a concern for Schmitt and Morgenthau. This sense of proportion and limit, essential to understanding the ethical dimensions of classical realist thought, provides a useful orientation for a pacifist ethos that seeks to address the problem of war, either current or prospective.

It may well be that the elimination of war between human communities is an unachievable goal and certainly any realist must accept that it is a permanent possibility, even in times of extended peace. It may also be the case that acceptance of our limits as human beings cannot advance our chances of reducing violence in the world in the ways I have suggested here. Nevertheless, in a context of increasing tensions in the South China Sea and intensifying violence in the Middle East and central Africa (amongst other conflicts scattered around the globe), it is incumbent upon us to examine all possible avenues for rethinking the place of pacifism and non-violence in responding to those crises. As Norberto Bobbio put it:

I am no optimist, but I do not infer from this that one should simply yield. The stakes are too high for us not to take up a position, each in our own place, even if the probabilities of victory are extremely slight. It has sometimes happened that a single grain of sand borne on the wind has brought some machine to a halt. Even if there were only the tiniest chance that a grain borne on the wind could end up in the $\operatorname{cogs}$ and gears of the mechanism and arrest its movement, the machine that we are now building is too monstrous for us not to challenge the power of fate (quoted in Zolo, 2010: 434). 
This flinging of grains of sand into the machine of political violence may be an unending and ultimately unsuccessful project. The pacifist ethos, drawing on a reflexive approach to realist thought, sketched out here may amount to no more or less than a horizon or orientation toward which we need to direct ourselves, even while acknowledging the unlikelihood of ever reaching it. The examination of the potentials and limits of pacifism necessitates, however, an encounter with a realist tradition that is richer in ethical resources than is often recognised in debates over war and peace in international relations.

Bibliography

Alexandra A. (2003) Political Pacifism. Social Theory and Practice 29(4): 589-606.

Alhaidar S. (2015) Our goal is to protect civilians: Al-Assiri. Arab News. (accessed 25 June 2015).

Brock P. (1970) Twentieth-century pacifism, New York ; London: New York ; London : Van NostrandReinhold.

Brock P. (1998) Varieties of pacifism: a survey from antiquity to the outset of the twentieth century, Syracuse, N.Y; Toronto?: P. Brock?

Cady DL. (1989) From warism to pacifism : a moral continuum, Philadelphia: Philadelphia : Temple U.P.

Chenoweth E, Stephan MJ and Ebooks C. (2011) Why civil resistance works: the strategic logic of nonviolent conflict, New York: Columbia University Press.

Cherniss JL. (2016) A Tempered Liberalism: Political Ethics and Ethos in Reinhold Niebuhr's Thought. Review of Politics 78(1): 59-90.

Cozette M. (2008a) Reclaiming the critical dimension of realism: Hans J. Morgenthau on the ethics of scholarship. Review of International Studies 34(1): 5-27.

Cozette M. (2008b) What Lies Ahead: Classical Realism on the Future of International Relations. International Studies Review 10(4): 667-679.

Cromartie M, Lewy G, Ethics, et al. (1990) Peace betrayed?: essays on pacifism and politics, Lanham, MD; Washington, D.C: Ethics and Public Policy Center.

Geuss R. (2008) Philosophy and real politics, Oxford; Princeton, NJ: Princeton University Press.

Geuss R. (2010) Politics and the imagination, Princeton, N.J: Princeton University Press.

Hobbes T. (2002) Leviathan. Kindle Edition ed.: Public Domain Books.

Holmes RL. (1989) On war and morality, Princeton, N.J: Princeton University Press.

Holmes RL. (1999) Pacifism for Nonpacifists. Journal of Social Philosophy 30(3): 387-400.

Holmes RL. (2015) The Metaethics of Pacifism and Just War Theory. The Philosophical Forum 46(1): 3-15.

Hom AR and Steele BJ. (2010) Open Horizons: The Temporal Visions of Reflexive Realism. International Studies Review 12(2): 271-300.

Howes DE. (2009) Toward a credible pacifism : violence and the possibilities of politics, Albany, NY: Albany, NY : SUNY Press.

Howes DE. (2013) The Failure of Pacifism and the Success of Nonviolence. Perspectives on Politics 11(2): 427.

Howes DE. (2015) The Just War Masquerade. Peace Review 27(3): 379-387.

Kant I. (1999) Toward Perpetual Peace. In: Gregor M (ed) Practical Philosophy. Cambridge, UK: Cambridge University Press. 
Kinsella DT and Carr CL. (2007) The morality of war: a reader, Boulder: Lynne Rienner Publishers.

Lazar S. (2010) The Responsibility Dilemma for Killing in War : A Review Essay. Philosophy \& Public Affairs 38(2): 180-213.

Lazar S. (2017) Just War Theory: Revisionists Versus Traditionalists. Annual Review of Political Science 20(1).

Lebow RN. (2003) The Tragic Vision of Politics: Ethics, Interests and Order, Cambridge: Cambridge University Press.

Mantena K. (2012) Another Realism: The Politics of Gandhian Nonviolence. Am Polit Sci Rev 106(2): 455-470.

May L. (2012) Contingent Pacifism and Selective Refusal. Journal of Social Philosophy 43(1): 1-18.

May L. (2015) Contingent pacifism: revisiting just war theory, Cambridge, United Kingdom: Cambridge University Press.

McMahan J. (2010) Pacifism and moral theory. Diametros (23): 44-68.

Molloy S. (2010) From the twenty years' crisis to theory of international politics: A rhizomatic reading of realism. Journal of International Relations and Development 13(4): 378-404.

Molloy Sn. (2006) The hidden history of realism: a genealogy of power politics, New York: Palgrave Macmillan.

Morgenthau H. (1951) In Defense of the National Interest: A Critical Examination of American Foreign Policy, New York: Knopf.

Morgenthau H. (1959) Correspondence: Dilemmas of Politics. International Affairs 35(4): 502.

Morgenthau H. (1974) Scientific Man vs. Power Politics, Chicago: University of Chicago Press.

Morgenthau H. (2006) Politics Among Nations: The Struggle for Power and Peace, New York: McGraw Hill.

Morgenthau H. (2012) The Concept of the Political, Houndmills: Palgrave Macmillan.

Neu M. (2011) Why There is No Such Thing as Just War Pacifism and Why Just War Theorists and Pacifists Can Talk Nonetheless. Social Theory \& Practice 37(3): 413-434.

Niebuhr R. (1940) Why the Christian Church is not pacifist, London: London : Student Christian Movement Press.

Niebuhr R. (2011) The Children of Light and the Children of Darkness: A vindication of democracy and a critique of its traditional defense, Chicago: University of Chicago Press.

Niebuhr R. (2013) Moral Man and Immoral Society: A study in ethics and politics, Louisville, KY: Westminster John Knox Press.

Ott DJ. (2012) Toward a Realistic, Public, Christian Pacifism. American Journal of Theology \& Philosophy 33(3): 245-257.

Pattison J. (2016) The Case for the Nonideal Morality of War: Beyond Revisionism versus Traditionalism in Just War Theory. Political Theory.

Reichberg GM. (2008) Jus Ad Bellum. In: May L (ed) War: Essays in Political Philosophy. New York: Cambridge University Press, 11-29.

Reitan E. (1994) The Irreconcilability of Pacifism and Just War Theory: A Response to Sterba (1992). Social Theory and Practice 20(2): 117-134.

Reitan E and Sterba JP. (1994) The irreconcilability of pacifism and just war theory: A response to Sterba--Comment/reply. Social Theory and Practice 20(2): 117.

Rodin D. (2002) War and self-defense, Oxford;New York;: Clarendon Press.

Rösch F. (2016) Unlearning modernity: A realist method for critical international relations? Journal of International Political Theory 13(1): 81-99.

Ryan C. (1983) Self-Defense, Pacifism, and the Possibility of Killing. Ethics 93: 508-524.

Ryan C. (2013) Pacifism, Just War, and Self-Defense. Philosophia 41(4): 977-1005.

Ryan C. (2015) Pacifism(s). The Philosophical Forum 46(1): 17-39.

Scheuerman W. (2007) Carl Schmitt and Hans Morgenthau: Realism and Beyond. In: Williams MC (ed) Realism Reconsidered: The Legacy of Hans J. Morgenthau in International Relations. Oxford: Oxford University Press, 62-92. 
Scheuerman W. (2011) The Realist Case for Global Reform, Cambridge: Polity.

Schmitt C. (1985) Political Theology: Four Chapters on the Concept of Sovereignty, Cambridge, MA: The MIT Press.

Schmitt C. (1996) The Concept of the Political, Cambridge, Mass. and London: MIT Press.

Schmitt C. (2003) The Nomos of the Earth, New York: Telos Press.

Schmitt C. (2007) Theory of the Partisan, New York: Telos Press Publishing.

Shue H. (2013) Laws of war, morality, and international politics: Compliance, stringency, and limits. Leiden Journal of International Law 26(2): 271-292.

Slomp G. (2006) Carl Schmitt's Five Arguments against the Idea of Just War. Cambridge Review of International Affairs 19(3): 435-447.

Steele BJ. (2007) 'Eavesdropping on honored ghosts': From classical to reflexive realism. Journal of International Relations and Development 10(3): 272-300.

Sterba JP. (1992) Reconciling Pacifists and Just War Theorists. Social Theory and Practice 18(1): 2138.

Sterba JP. (1994) Reconciling Pacifists and Just War Theorists Revisited. Social Theory and Practice 20(2): 135-142.

Sterba JP. (1999) Five Commentators: A Brief Response. Journal of Social Philosophy 30(3): 424-437.

Tellis AJ. (2006) Morgenthau: Politics as the Struggle for Power. In: Thompson KW and Clinton WD

(eds) Politics Among Nations: The Struggle for Power and Peace. 7th ed. New York: McGraw Hill, 607-616.

Tjalve VS. (2008) Realist Strategies of Republican Peace: Niebuhr, Morgenthau, and the Politics

of Patriotic Dissent, New York: Palgrave Macmillan.

Tjalve VS and Williams MC. (2015) Reviving the Rhetoric of Realism: Politics and Responsibility in Grand Strategy. Security Studies 24(1): 37-60.

Waltz K. (1970) Man, the State and War: A Theoretical Analysis, New York: Columbia University Press.

Walzer M. (1992) Just and Unjust Wars, New York: Basic Books.

Williams MC. (2005) The Realist Tradition and the Limits of International Relations, Cambridge:

Cambridge University Press.

Williams MC. (2007) Realism reconsidered: the legacy of Hans Morgenthau in international relations, Oxford;New York;: Oxford University Press.

Yoder JH. (1976) Nevertheless: the varieties and shortcomings of religious pacifism, Scottdale, Pa: Herald Press.

Yoder JH. (1996) When war is unjust: being honest in just-war thinking, Maryknoll, N.Y: Orbis Books. Zolo D. (2010) Insights and Obscurities of "Juridical Pacifism" in Norberto Bobbio. Iris 2(4): 423.

\footnotetext{
${ }^{1}$ Ethos, in this sense, follows the path set by Reinhold Niebuhr, in referring to 'a disposition rather than a doctrine', a 'spirit' or 'temper' that espouses moral or ethical principles 'which must be approximated, without ever being fully realized, in imperfect earthly justice.' See Cherniss JL. (2016) A Tempered Liberalism: Political Ethics and Ethos in Reinhold Niebuhr's Thought. Review of Politics 78(1): 59-90.

${ }^{2}$ It is worth noting here that the connection (or lack of) between Morgenthau's depiction of human nature and his political theory was central to Waltz's critique of 'first image' theories in Man, the State and War. Here Waltz argues that an understanding of politics 'cannot be derived' from an understanding of man Waltz K. (1970) Man, the State and War: A Theoretical Analysis, New York: Columbia University Press. Yet these connections are made explicit in Morgenthau Morgenthau H. (2012) The Concept of the Political, Houndmills: Palgrave Macmillan. and Schmitt's Schmitt C. (1996) The Concept of the Political, Cambridge, Mass. and London: MIT Press. texts, both titled The Concept of the Political, neither of which are cited in Waltz's critique.
} 